E3S Web of Conferences 1, 08001 (2013)

DOI: $10.1051 / \mathrm{e} 3$ sconf/20130108001

(c) Owned by the authors, published by EDP Sciences, 2013

\title{
Effects of Long Term Hg Contamination on Soil Mercury Speciation and Soil Biological Activities
}

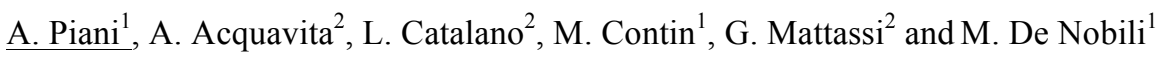 \\ ${ }^{1}$ Dipartimento Scienze Agrarie ed Ambientali, University of Udine, Udine, ITALY, piani.alberto@spes.uniud.it \\ ${ }^{2}$ Agenzia per la Protezione dell'Ambiente del Friuli Venezia Giulia, ARPA FVG, Palmanova (UD), ITALY
}

\begin{abstract}
The suspended matter discharged by the Isonzo river has carried over, for centuries, heavily contaminated mine spoils from the Idrija mercury mining site (Slovenija). A frequently flooded area at the confluence of the Isonzo and Torre rivers was chosen for a preliminary study on the effects of long term mercury pollution on soil biological activities, $\mathrm{Hg}$ speciation and plant bioavailability. Soil mercury contamination reached up to about $80 \mu \mathrm{g} \mathrm{g}^{-1}$ near the banks of Isonzo river and decreased down to about 0.2 $\mu \mathrm{g} \mathrm{g}^{-1}$ near the Torre river, with the predominance of mercuric sulfide and elemental mercury. Soil microbial biomass was not adversely affected by $\mathrm{Hg}$ contamination as most soil biological activities, with the exception of arylsulphatase and acid phosphatase, which showed significant negative trends against total mercury and its fractions. Two plant genres (Arum spp. and Rubus spp.) were collected in four different places: Rubus spp. showed the largest uptake capacity of mercury (about $1 \mu \mathrm{g} \mathrm{g}^{-1}$ ). Long term mercury contamination does not seem to constitute a stressing factor for soil biological activities but remains nevertheless a concern for its transfer through the food chain.
\end{abstract}

Key words: Mercury, Idrija mine, $\mathrm{Hg}$ speciation, soil microbial biomass, soil biological activity, plant $\mathrm{Hg}$ uptake.

\section{Introduction}

The mercury mine of Idrija (Slovenija), the second largest mercury mine in the world, was active since the Roman age until 1995. Its heaviest exploitation period occurred during the last century, but inefficient processing of ores and careless disposal of mine spoils caused the contamination of the nearby river Idrijca since the Middle Ages. It was estimated that 12 million tons of $\mathrm{Hg}$ ore have been excavated, of which more than $35,000 \mathrm{t}$ have been lost into the environment during smelting (Kotnik et al., 2005). Despite the closing of the mine, contamination is still going on, because of the sediments carried downstream and eventually deposited by flooding waters. The Idrijca river is a tributary of the Soča river, which flows through the Friulian plain under the Italian name of Isonzo. This has brought to the contamination of the banks of this river system (Candussio and Visintini Romanin, 1983; Hines et al., 2000) and even of the Gulf of Triest (Faganeli et al., 2003) and originated along the course of the Isonzo a rare situation of severe long term pollution in a mostly natural and partly cultivated environment.

Mercury is known as one of the most toxic elements for humans and for biological systems in any of its forms, even if the most dangerous form is methylmercury $(\mathrm{MeHg})$, which can be accumulated through the food chain and causes neurological disease (Boening, 2000; Adriano, 2001).

The role of soils in mercury sequestration and of soil microbial biomass in mercury transformation has been studied in deep as regards short-term contamination and in vitro experiments, but there is a lack of data about the long term effects of this element on soil microbial biomass, soil biological activity as well as its speciation and bioavailability as a result of long term contamination. The aim of this work was to determine the $\mathrm{Hg}$ distribution in soils, its bioavailability for plants and effects on soil biological activities in a long term contaminated area.

\section{Materials and Methods}

The study area is located at the confluence of the Isonzo and Torre rivers, in the Eastern part of the Friulian plain (Friuli Venezia Giulia, Italy): this particular location was chosen because of the documented recurrent inundations by the Isonzo river. Samplings were performed in 2011 
during winter and autumn; soils were sampled along a transept and across this along a north-south direction to the river bank, up to a depth of $30 \mathrm{~cm}$. Soil samples were sieved at $2 \mathrm{~mm}$ and stored moist at $4^{\circ} \mathrm{C}$. Mercury speciation and total $\mathrm{Hg}$ content were performed according to a method based on sequential selective extractions (Bloom et al., 2003) as subsequently modified by Shi et al. (2005). In order to study the uptake of mercury by plants, four sites were chosen to sample two of the most widespread genres in the area: Rubus spp. and Arum spp. Three specimens per site for each genre were collected, plants were divided into hypogeal and epigeous tissues and oven-dried at $60^{\circ} \mathrm{C}$. Plant samples were then grinded and analyzed for $\mathrm{Hg}$ with an AMA 254 (LECO Corporation U.S.A.).

Grinded soil samples were analyzed with a Carlo Erba Instruments, Na 155 Series 2, Nitrogen/Carbon/ Sulphur Analyzer for total carbon and nitrogen. A set of biological parameters was measured to assess soil biological activities after 7 days of incubation at $25^{\circ} \mathrm{C}$ and 50\% WHC. Soil microbial biomass was measured with the fumigation-extraction method (Vance et al., 1987) while soil respiration was measured at 3, 11 and 25 days of incubation (as reported by Alef and Nannipieri, 1995). Soil biological activities were estimated through a set of colorimetric assays: FDA hydrolyis, arylsulphatase, $\beta$-glucosidase, alcaline and acid phosphatase (as reported by Alef and Nannipieri, 1995). Soil respiration and soil biological acitivities were also normalized with respect to soil microbial biomass $\mathrm{C}$ (specific activities).

All measurements were performed in triplicate and are expressed on the basis of oven-dry matter. Data were statistically analysed by R software (R Development Core Team, 2010; Husson et al., 2010).

\section{Results and Discussion}

The soils sampled are mostly sandy loam soils with an organic carbon content from 10 to $25 \mathrm{mg} \mathrm{g}^{-1}$ (average: 16 $\mathrm{mg} \mathrm{g}^{-1}$ ), well within the normal range for these type of soils in the region. Their average $\mathrm{C}: \mathrm{N}$ ratio is 8.8 (range: $8.2-9.8$ ), which is consistent with good mineralization and humification processes in aerobic soils.

The average $\mathrm{pH}$ value of the topsoil is slightly alkaline (range: $7.78-7.98$, average: 7.8).

Mercury contamination results to be more severe near the banks of Isonzo river (up to about $76 \mu \mathrm{g} \mathrm{g}^{-1}$ ) and negligible $\left(0.2 \mu \mathrm{g} \mathrm{g}^{-1}\right)$ nearer to the banks of Torre river, showing a general irregular, but negative trend with the distance from the Isonzo river. A sequential extraction composed by five steps was applied to separate the following operationally defined $\mathrm{Hg}$ species: water soluble (Hg-w), human stomach acid soluble (Hg-h), organo-chelated (Hg-o), elemental (Hg-e) and mercuric sulphide (Hg-s). As shown in Fig. 1, the distribution of mercury fractions is similar among the sampling sites: by far the most abundant fraction is Hg-s, mostly coinciding with mercuric sulfide, whereas Hg-e (elemental mercury) is the second most abundant fraction; all the other fractions are only scarcely represented.

$\mathrm{Hg}$-s and $\mathrm{Hg}$-e together can be considered as the more immobile and less bioavailable fractions of mercury which in this case range from 0.09 to $75.95 \mu \mathrm{g} \mathrm{g}^{-1}$. These fractions are probably directly derived from respectively ancient (Hg-s) and more recent (Hg-e) mine spoils materials (Hines et al., 2000), while $\mathrm{Hg}-\mathrm{w}$ and $\mathrm{Hg}-\mathrm{h}$ together constitute the mobile and bioavailable fraction of the metal which ranges up to $1 \%$ of total mercury in the sampled soils.

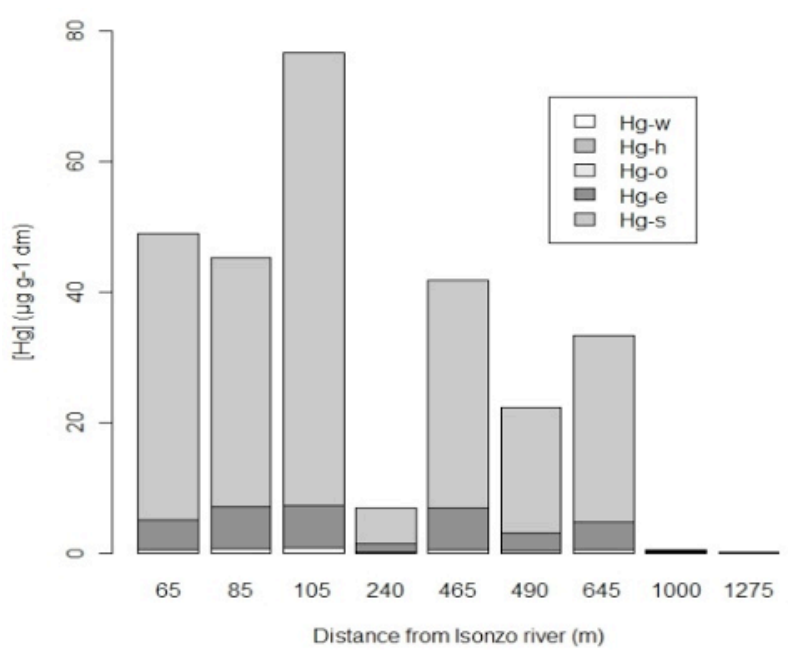

Fig. 1: Total mercury and mercury speciation at various distances from the Isonzo river bank.

None of the fractions shows any clear relationship with soil clay, organic $\mathrm{C}, \mathrm{C}: \mathrm{N}$ ratio or $\mathrm{pH}$, so in this area there does not seem to be any link between soil physicochemical parameters and the distribution of mercury in the different fractions. This is somehow in contrast with the findings of previous studies (Boening, 2000; Adriano, 2001; Boszke et al., 2008).

Soil microbial biomass $\mathrm{C}$ shows a wide range of variation within the area $\left(179-765 \mu \mathrm{g} \mathrm{C} \mathrm{g}^{-1}\right)$ with an average of $477 \mu \mathrm{g} \mathrm{C} \mathrm{g} \mathrm{g}^{-1}$ and displays the expected positive correlation with organic carbon but no clear correlation trends with total $\mathrm{Hg}$ or any $\mathrm{Hg}$ fraction, indicating the absence of adverse effects of the metal on soil microbial biomass.

Soil respiration and specific soil respiration do not show any clear trend with soil organic carbon and neither show any significant decrease at high levels of contamination, confirming the absence of stress situations in the soils of the area.

Soil biological activities, as well as specific soil biological activities, show in fact, as normally expected, generally positive correlations with soil microbial biomass $\mathrm{C}$ and soil organic carbon: the only exception to these trends is represented by q-FDA which shows a negative trend with soil organic carbon.

Three soil biological activities (FDA, $\beta$-glucosidase and alkaline phosphatase) display weak negative correlations (or a substantial stability) with total mercury and its fractions and the same trend against mercury is displayed by their specific activities.

The characteristics of the studied pollution (in particular the long period of time during which it has 
occurred) allowed to expect no significant negative trends of the soil biological activities against total mercury or any of its fractions, in the hypothesis of a possible adaptation of soil microorganisms.
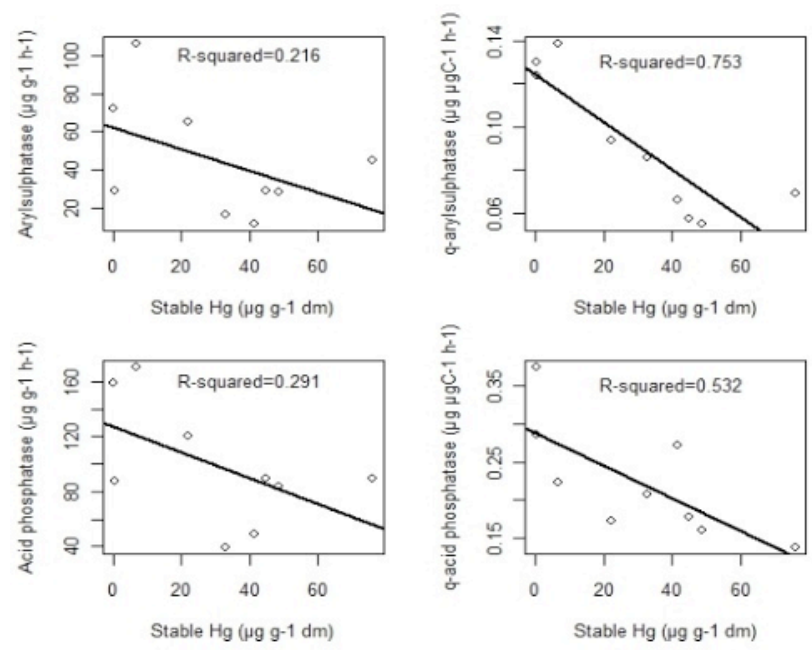

Fig.2: Soil biological activities showing negative correlations against the stable mercury fraction.

Arylsulphatase and acid phosphatase shows, instead, negative trends against each of the mercury fractions, in particular against the most stable ones. As can be seen in Fig. 2, arylsulphatase and acid phosphatase are apparently negatively correlated with stable mercury fractions, but the correlation is not significant even if it improves if specific activities are considered. Specific arylsulphatase and specific acid phosphatase show indeed a significant negative trend against the stable fraction of mercury similarly to what observed by Kuperman and Carreiro (1997) and Casucci et al. (2002).

These results allow us to identify only a possible limited situation of stress in the sampled soils as shown by significant adverse effects on arylsulphatase and acid phosphatase.

The analysis of plants tissues states the transfer of mercury from soil to plants: Fig. 3 displays the differences in metal uptake between hypogeal and epigeous tissues. The tissues showing the most relevant uptake in each of the species are the roots, with a higher concentration in Rubus spp.. Arum spp. and Rubus spp. actually also show a low contamination of the epigeous parts, so both translocation inside the plant and the air transfer of volatile mercury forms from soil to tissues could be assumed to constitute minor pathways of plant uptake. Hypogeal tissues show a stronger uptake of the metal from soil (average values of $0.3 \mu \mathrm{g} \mathrm{g}^{-1}$ for Arum spp. and $1 \mathrm{\mu g} \mathrm{g}^{-1}$ for Rubus spp.). The early stage of development at which plants were sampled and the ecological characteristics of the species support concern about larger contamination of plants at their complete development stage and potential transfer through the food chain. This hypothesis are supported by the findings of García-Sánchez et al. (2009) who observed a similar mercury transfer from soil to plants near the mining site of Usagra (Spain), even if the contamination levels of the site are incomparably higher than those measured in this work.
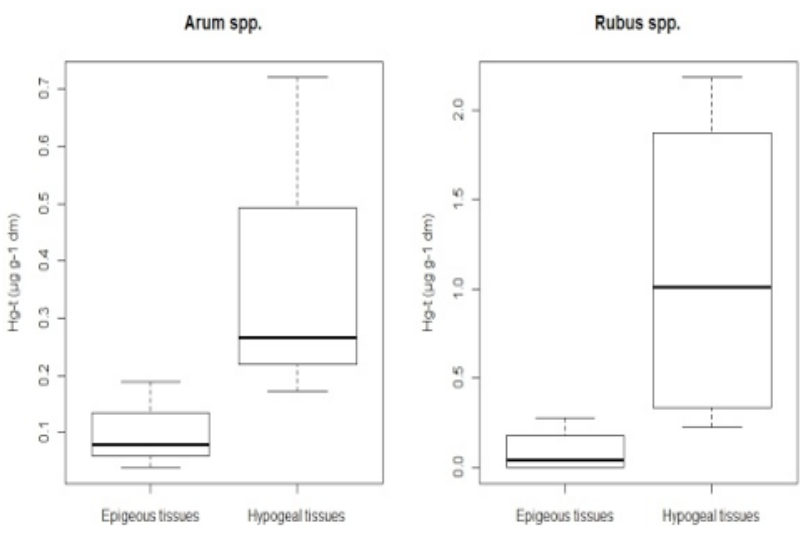

Fig. 3: Plant mercury uptake in the study area.

\section{Conclusions}

The soils of the area are characterized by severe mercury contamination (up to about $80 \mu \mathrm{g} \mathrm{g}^{-1}$ ) which decreases moving away from the banks of Isonzo river. Speciation of mercury in soils shows that mercury is mostly present as mercuric sulfide, probably directly derived from the cinnabar transported by Isonzo river: the contamination is then principally constituted by the immobile fraction of mercury, as already observed upstream by Biester et al. (2000) in the floodplain of Idrijca river. Mercury deposited by flood water appears to be still immobilized in the alluvial soils formed near the river banks.

Soil microbial biomass does not seem to be influenced by mercury contamination, contrasting the observations by Harris-Hellal et al. (2009). This parameter does not therefore appear to be a suitable stress indicator for situations affected by long term contamination. This is also confirmed by soil respiration trends against total and fractionated mercury which, differently from what reported by Giller et al. (1998), do not suggest any toxicity stress. This could possibly be, on one side, the result of a successful adaptation of the soil microbial biomass to the slow and long term contamination of the site. On the other hand, it may be also the result of the stronger resilience of a nearly natural environment to toxicity stress, as compared to situations commonly found in industrial sites.

Soil biological activities appear to be influenced by mercury contamination only in part: only arylsulphatase and acid phosphatase, and in particular their specific rates, display a significant reduction of activity at high mercury concentration for each metal fraction. Reduction in these two biological activities could influence, in principle, the mineralization of organic phosphate and sulfur eventually resulting in negative effects on the ecosystem functions, however the $\mathrm{C} / \mathrm{N}$ ratios of the soils indicate, on the contrary, a normal and efficient catabolism of soil organic matter.

Even if mainly stable, mercury in the area is transferred to plant roots: this constitutes a concern for its implications in the food chain. 
This area should be further and thoroughly investigated including an extensive and periodic sampling of the vegetation in order to verify the factors linked to $\mathrm{Hg}$ immobilization in soils, soil microbial biomass dynamics as well as $\mathrm{Hg}$ effects on the ecosystem.

\section{References}

Alef K, Nanninpieri P. Methods in Applied Soil Microbiology and Biochemistry. Academic Press Limited 1995.

Adriano DC. Trace Elements in Terrestrial Environments. Springer 2001. 411-458.

Biester H, Gosar M, Covelli S. Mercury Speciation in Sediments Affected by Dumped Mining Residues in the Drainage area of the Idrija Mercury Mine, Slovenia. Environmental Science and Technology 2000. 34:3330-3336.

Bloom NS, Preus E, Katon J, Hiltner M. Selective extractions to assess the biogeochemically relevant fractionation of inorganic mercury in sediments and soils. Analytica Chimica Acta 2003. 479:233-248.

Boening DW. Ecological effects, transport, and fate of mercury: a general review. Chemosphere 2000. 40:1335-1351.

Boszke L, Kowalski A, Astel A, Barański A, Gworek B, Siepak J. Mercury mobility and bioavailability in soil from contaminated area. Environmental Geology 2008. 55:1075-1087.

Candussio R, Visintin Romanin M. Ricerca sul mercurio negli ambienti agrari della regione Friuli Venezia Giulia. Istituto Sperimentale per la Nutrizione delle Piante 1981.

Casucci C, Okeke BC, Frankenberger Jr. WT. Effects of Mercury on Microbial Biomass and Enzyme
Activities in Soil. Biological Trace Element Research 2003. 94:179-191.

Kuperman RG, Carreriro MM Soil heavy metal concentrations, microbial biomass, and enzyme activities in a contaminated grassland ecosystem. Soil Biology and Biochemistry 1997. 29:179-190.

García-Sánchez A, Murciego A, Álvarez-Ayuso E, Santa Regina I, Rodríguez.González MA. Journal of Hazardous Materials 2009. 168:1319-1324

Giller KE, Witter E, McGrath SP. Toxicity of Heavy metals to Microorganisms and Microbial Processes in Agricultural Soils: a Review. Soil Biology and Biochemistry 1998. 30:1389-1414.

Harris-Hellal J, Vallaeys T, Garnier-Zarli E, Bousserrhine N. Effects of mercury in soil microbial communities in tropical soils of French Guyana. Applied Soil Ecology 2009. 41:59-68.

Hines ME, Horvat M, Faganeli J, Bonzongo JCJ, Barkay T, Major EB, Scott KJ, Bailey EA, Warwick JJ, Lyons WB. Mercury Biogeochemistry in the Idrija River, Slovenia, from above the Mine into the Gulf of Trieste. Environmental Research 2000. 83:129-139.

Kotnik J, Horvat M, Dizdarevič T. Current and pat mercury distribution in air over the Idrija mercury mine region, Slovenia. Atmospheric Environment 2005. 39:7570-7579.

Shi J, Liang L, Jiang G, Jin X. The speciation and bioavailability of mercury in sediments of Haihe River, China. Environment International 2005. 31:357-365.

Žibret G, Gosar M. Calculation of the mercury accumulation in the Idrijca River alluvial plain sediments. Science of the Total Environment 2006. 368:291-297. 